\title{
Riding High in the Saddle: African American Subversion in the 1930s Western
}

\section{Susan Savage Lee}

\section{(2) OpenEdition \\ 1 Journals}

Electronic version

URL: https://journals.openedition.org/ejas/16890

DOI: $10.4000 /$ ejas. 16890

ISSN: 1991-9336

\section{Publisher}

European Association for American Studies

\section{Electronic reference}

Susan Savage Lee, "Riding High in the Saddle: African American Subversion in the 1930s Western", European journal of American studies [Online], 16-2 | 2021, Online since 13 July 2021, connection on 17 October 2022. URL: http://journals.openedition.org/ejas/16890 ; DOI: https://doi.org/10.4000/ejas. 16890

This text was automatically generated on 17 October 2022.

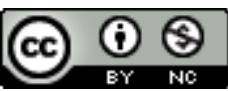

Creative Commons - Attribution-NonCommercial 4.0 International - CC BY-NC 4.0 https://creativecommons.org/licenses/by-nc/4.0/ 


\title{
Riding High in the Saddle: African American Subversion in the 1930s Western
}

\author{
Susan Savage Lee
}

\section{Introduction}

1 On November 11, 1937, the New York Times ran a story about thirteen-year-old William Troeller's suicide. When the reporter asked the family for a possible reason behind the boy's death, his brother attributed Troeller's act to "hunger." While Troeller's actions may have been unique, his feelings of desperation were less so for other African Americans in the 1930s. After the 1929 stock market crash, desperate acts by everyday citizens occurred all too often as the American capitalist economy crumbled with little hope of immediate recovery. Despite their poverty, many Americans turned to the glamorous world of the movies in an effort to escape dire circumstances like these. Historian Robert S. McElvaine has argued "nothing was as central to American popular culture in that decade [the 1930s] as motion pictures... Almost everyone who could afford to (and millions who could not) went to the cinema frequently throughout the decade" (88). During the early 1930s, he reports, U.S. moviegoers purchased an average of 60 to 75 million movie tickets each week (88). Captivated by the introduction of sound in film, Americans watched glamorous story lines come to life, which temporarily eased the realities of unemployment and poverty.

During the 1930s, however, the United States saw the demographic profile of moviegoers change. Andrea Mattacheo describes the Great Depression as an era that presented Americans "with the possibility of failure" (169), and it "taught Americans to be afraid of desires" (qtd. in Mattacheo 169). Despite this depressing atmosphere, or perhaps because of it, working class and minority groups flocked to movie houses in their neighborhoods as an escape. The preoccupations of working class and minority audiences guided which movies they watched. African American audiences, for 
example, were tired of stereotypical portrayals of themselves in film. Immigrants and the working class, who were also among film's consumers, wanted to see more relevant and realistic portrayals of their lives when they went to the cinema (Leyda 49). American studios complied. Eager to include this untapped market as potential moviegoers, minority filmmakers and screenwriters, such as African American Spencer Williams developed movies with diverse audiences like these in mind.

3 Although Williams gained access to filmmaking, he still had to comply with legal and social norms. Racism and segregationist tactics like Jim Crow laws restricted Williams. To combat these restrictions, Williams turned to a popular mainstream genre: the western. Williams's star actor, Herbert Jeffries explained that black westerns "were just like white Westerns. The family mine was being foreclosed. There was a fight over water rights. A pretty girl had been kidnapped" (Bogle 172). The film begins with Bob Blake and his sidekick, Dusty, looking for adventures. They stumble upon the Dennison ranch where it appears that a murder has taken place, although the ranch owner, Jim Dennison is still alive. The two heroes later find out that Bradley, the film's villain, is trying to seize the ranch by terrorizing Jim. Bradley wants the property in order to make use of the radium mine beneath it. In order to get rid of the heroes so that he can exact his plan, Bradley frames Bob for a murder by planting one of his gloves at the crime scene. By the end of the film, Bob falls in love with Jim's daughter and clears his name. The Dennisons are then free to live on their property without the nefarious Bradley tormenting them. The plots mentioned by Jeffries are clearly evident in Williams's Harlem Rides the Range (1939). At the same time, by removing Anglo culture from his film and populating it with African Americans instead, Williams eradicates the white supremacy that often undergirded representations of cross-cultural conflicts in white-made cinema.

4 By adopting a popular genre like the western, Williams brought minority perspectives to the silver screen during a period when these perspectives were often met with hostility or completely ignored within mainstream culture. In doing so, Williams includes elements of the western that are familiar to audiences, such as the singing cowboy genre. He then pairs this familiar element with subversive ones like the use of dialect and the trickster figure. Through an analysis of Williams's adhesion to and disruption of tendencies in the western, it becomes clear how he appealed to both white and black audiences during a period of poverty, unemployment, and segregation. In addition to this, a closer look at William's manipulation of a western like Harlem Rides the Range helps locate and explore black identity in early cinema history.

\section{Going to the Movies}

5 In the 1930s, American filmmakers and production companies paid close attention to audience demographics. McElvaine suggests that film producers were "guided by the profit motive and so had an incentive to give moviegoers what they wanted to see" (89). In previous decades, the western was often used as a vehicle for assimilation, schooling marginalized groups in how to be American. But these groups were not passive, accepting recipients of assimilation tactics, for the basic themes of the western, such as the triumph of good over evil, were incredibly compelling to both minority and mainstream audiences. As a result, minority filmmakers happily turned to 
the western to explore its theme of good versus evil without relying on rhetorics of exclusion that alienated the moviegoers who were immigrants or people of color.

While Hollywood production companies like Paramount, Loew's, Fox, Warner Brothers, and R.K.O were successful in international markets, they also dominated the American scene (Cohen 126). In 1930 alone, releases like Fox's The Big Trail and Universal's All Quiet on the Western Front had budgets over two million dollars. These budgets gave them access to the latest equipment (for example, The Big Trail used 70mm film) and the ability to produce more sophisticated images. Large budgets also attracted well-known actors who expected high salaries, but who also had the potential to create box office hits.

7 For minority filmmakers, particularly African Americans, competing against Hollywood blockbusters proved to be incredibly difficult. Independent black filmmakers in the United States experienced financial problems evident, for example, in the fate of Noble Johnson's Lincoln Motion Picture Company, which went bankrupt in the 1910s (Bogle 23). In order to be competitive, African American filmmakers adopted popular genres like the western and detective stories. In addition to their wide appeal, these genres required small budgets. Westerns could be produced nearly anywhere--whether filmed on a set or in the middle of California, the genre permitted a range of budgets to participate in its creation. At the same time, audiences did not expect sophisticated aesthetics in westerns; instead, they enjoyed predictable plots. In fact, The Big Trail's enormous budget was an anomaly; most successful westerns of the time had small budgets because they used limited special effects. Despite the limitations posed by inadequate funding, minority filmmakers did have access to sound which by the late 1930s was a standard feature. Because of the versatility and inexpensive nature of the western, it offered minority filmmakers options irrespective of their financial constraints.

Ironically, discrimination played a role in launching the careers of African American filmmakers. As historian Lizabeth Cohen points out, black workers "found themselves laid off in greater numbers than white workers" during the Great Depression (331). The press, however, tended to lambast unemployed African Americans, suggesting that the "stigma of relief [is] practically non-existent among Negroes" (Coode and Bauman 63). While 25 percent of the African American population in New York received relief, southern African Americans were often denied assistance and remonstrated to "go pick cotton" (Hoyt 82). The Depression exacerbated the inequality blacks already faced under Jim Crow laws. This was even true in movie theaters, where, as Cohen points out, black audiences could only sit in balconies, the worst seating to watch movies in predominately white neighborhoods (121). In addition, minority audiences struggled to find money to attend the picture palace shows in upper-class neighborhoods, thus relegating them to the neighborhood theaters where the price of admission was cheaper (123). Because the picture palace shows with the latest Hollywood films were too expensive, African American audiences found themselves in the multitude of neighborhood theaters which offered a different kind of fare. Ebony pictures, for example, provided over 700 movie picture houses for black audience in the 1920s alone (Kagan 13). Neighborhood theaters, unable to afford the high cost of Hollywood distribution, featured small budget films like westerns and detective stories. Westerns thus became familiar to African American audiences despite their frequent trafficking 
in white supremacy. This meant, however, that a door was open for minority adaptations of the western to emerge and be well received.

African American audiences rarely encountered black actors in Hollywood films, and when they did, they had limited roles. During the 1930s, African American novelist Richard Wright complained "we have already enough plays and movies showing Negroes in... traditional roles" (qtd. in Denning 398). In the early years of cinema, black actors could not find roles in major productions (Bogle 138). White actors wearing blackface played black characters. In the 1910s, black audiences would see very few African Americans in any type of role. During the 1920s, however, Hollywood hired African American actors only to play stereotypical parts with little chance for the lead. Later, African Americans played marginal roles to avoid transgressing the 1934 production code that prohibited miscegenation on-screen (Smyth 24).

off-screen, the limitations imposed on black actors had mixed consequences. Actors like Stepin Fetchit reaped financial success for catering to stereotypes in films like John Ford's Salute (1929). In addition, actors like Fetchit were targets of frequent criticism from the black community because they accepted stereotypical roles that reinforced black marginalization. To a certain degree, Fetchit's critics were right. Hollywood producers relegated black actors to domestic roles. Film historian Donald Bogle claims that white audiences viewed popular actors like Fetchit as "a representative of the American Negro" (43). In contrast to Fetchit's critics, some black moviegoers recognized the difficulties black actors faced in Hollywood. Vocalist Etta James once explained "black actors were heroes. They might play fools on the screen, but the folks in the neighborhood knew it took more than a fool to break into lily-white Hollywood" (117). Roles for black actors were therefore complicated because they both reinforced and negated stereotypes of African Americans depending on the moviegoer's perspective. While black actors and writers, such as Langston Hughes made inroads in theater in the 1930s, Michael Denning explains "Hollywood's color line prevented the Harlem theater artists from having a major impact on Hollywood in the 1930s and 1940s" (370).

11 Before minority adaptations of the western in the 1930s, some studios, such as the Famous Artists Company, recognized black spectatorship as an untapped corner of the market. Before the 1930s, three films were produced with an African American audience in mind: Ten Nights in a Barroom (1926), Scar of Shame (1929), and Green Pastures (1929). Because 70 percent of both white and black Americans continued to attend movies at least once per week during the Great Depression, Hollywood producers realized there was financial potential in developing all-black films. These films, however, were anomalies until African Americans like Oscar Micheaux and Spencer Williams attempted to make their own movies as independent contractors in the 1930s (Bogle 104). Although film scholar Thomas Cripps argues that Williams's race films were directed solely toward a black audience (138), according to Jane M. Gaines, filmmakers like Williams also expected a portion of their audience to be white, in particular whites who could be converted to "another point-of-view" (66). At the same time, minority producers could only strike out a handful of film prints, in contrast to Hollywood productions, thus increasing the likelihood that the films would be lost for future generations (Stewart 149). 


\section{Black Filmmakers in Hollywood and Harlem Rides the Range}

Before the 1910s, Paul C. Heyde indicates that "the film industry was almost exclusively white-run" (8). After that decade, African American film companies and filmmakers began to appear (8) Although independent black productions were eventually squeezed out (Kagan 14), for a brief period of time, African American audiences eagerly consumed movies like Harlem Rides the Range and The Bronze Buckaroo because, as Julia Leyda points out, they offered the comfort of watching movies in black venues instead of segregated theaters (50). In addition, African American audiences had already been primed for films like Harlem Rides the Range because of their exposure to "race records" produced by black-owned companies like Black Swan Records and white labels like Paramount and Columbia (Cohen 155). As a consequence, films like Harlem Rides the Range already had established audiences.

13 African American filmmakers and screenwriters like Williams, however, understood reaching black audiences still required a different approach than the one utilized by the music industry. As a result, Williams developed parts for black actors, while producer Richard C. Kahn employed black actors to play leading roles. Williams also incorporated black culture into his westerns in order to counter Hollywood stereotypes. According to Terri Francis, westerns like Harlem Rides the Range represent a kind of "role play in which African American writers, actors, directors, and their audiences, cut across normative boundaries of black identification in Hollywood and in the real world to assert as post-civil rights masculinity based on both pleasure and power" (43). Although Francis refers to westerns like Django Unchained and Buck and the Preacher rather than Harlem Rides the Range, Francis's emphasis on black identity construction is also a large component of early era westerns like Williams's film. Leyda argues, furthermore, that "the black-audience entertainment films of the 1930s consists of adaptations of popular white genre films that do not directly portray racism or white-supremacist violence" (47). Williams's films, therefore, combined the familiarity of the western with black cultural relevancy and identity formation.

Black westerns also tend to belong to the sub-genre of singing cowboy movies. According to Mark Fenster, the singing cowboy genre begins with John A. Lomax's 1910 book, Cowboy Songs and Other Frontier Ballads, a tradition later picked up by the film industry in the 1920s (260). Many singers like Harry McClintock recorded cowboy songs, limiting themselves to the genre (271). This genre was familiar to racially diverse audiences enamored by white singing cowboys like Gene Autry, and by participating in it, films like Williams's helped demonstrate that black actors could sing, dance, and play starring roles. Although Joel Dinerstein argues in his work on film noir that the short prewar era provided a "window of opportunity for the production of films that darkly illuminated the collapse of the nation's myths and symbols, its lost faith in businessmen and the work ethic, its first bouts of technological pessimism and class warfare" (419), singing cowboy movies still retained their popularity despite the effects of the Great Depression. In her analysis of the impact of singing cowgirls, Stephanie Vander Wel explains that during the Great Depression, singing cowboys and cowgirls offered "hope and promise to those suffering the devastating effects of rural poverty, urban unemployment and migration" (208). For African American actors, singing cowboy movies offered opportunities both on and off-screen. In Hollywood, directors 
had already associated black actors with singing and dancing because of American interest in "race records," largely comprised of jazz and blues music in the 1920 s. Hollywood producers recognized the crossover appeal of jazz, viewing music as a vehicle to increase film's appeal (Bogle 82). Despite their talents, black actors and actresses never attained starring roles in Hollywood films of the 1920s or 1930s. Blackmade films like Williams's Harlem Rides the Range, however, gave its star Herbert Jeffries, an opportunity to perform the role of the heroic singing cowboy, which was a clear departure from Hollywood's tendency to marginalize black talent. According to Tia C. M. Tyree and Liezille J. Jacobs, black heroes help describe how blacks are viewed and constructed in the world (2). In addition to this, Jeffries's singing cowboy routine, as Leyda notes, permitted black audiences access to all "locations in life, both high and low and even tall in the saddle" (50). In retrospect, these films also offer "meaningful encounters with the past" (Stewart 153).

In Harlem Rides the Range, however, Bob Blake's songs challenge the singing cowboy western's traditional content because they incorporate black culture into their lyrics. It is in this context that Williams creates his singing cowboy hero, Bob Blake. Williams includes cowboy songs sung by the film's hero in order to present what Leyda calls "a plausible rendered anatomy of black life" (56). Western musicals like Gene Autry's generally included specific types of songs that describe the cowboy's love of the frontier, a woman, or his occupation or, what Vander Wel calls the songs' "gendered imagery" (209). Blake's songs initially appear to present the same content, particularly his first ballad, "I'm a Happy Cowboy," that begins with a romanticized portrayal of the landscape, or a way of soothing the concerns of the era in singing cowboy movies (Vander Wel 209). The sadness of coming home to an empty house replicates the traditional content of many cowboy songs; however, the song also departs from tradition with the following line: "the Lord will call him [the cowboy] home" (Williams). In doing so, the song draws as much on the musical traditions of black spirituals as it does on the tradition of cowboy songs. Williams understood folk cultures intimately so he often included their themes and characteristics in his films (Seward 3). Although this idea mainly pertains to Williams's religious films, black folk music is an important element in William's westerns as well. As a result, Williams's work resonated with diverse audiences familiar with Autry, yet also functioned as a way to bring cultures together. This enabled African American audiences to explore black cultural traditions in the film and to participate in large-scale U.S. popular culture.

Williams uses Blake's first ballad to both reinforce and subvert the western's traditional content. In a manner congruent with other singing cowboy westerns, Blake's first ballad separates the hero from the film's villains, such as Jim Connors (Tom Southern). One evening at Watson's (Spencer Williams) ranch, for example, the men gather in the bunkhouse, entertaining themselves as darkness falls. After discovering blood at Dennison's (Leonard Christmas) ranch earlier in the day, Blake and Watson now discuss Blake's suspicions that the ranch owner met with foul play. While they carry on their conversation, Connors sits at a table, playing solitaire and eavesdropping. Blake turns to Connors and gives him some advice about playing cards. Connors reminds Blake that his game is solitaire, abruptly dismissing Blake's friendly gestures and locating himself as a purposeful outsider. During Blake's song, Connors stands towards the edge of the frame, cast in shadows, while the other ranch hands join in the merriment, providing harmonic accompaniment in a call-and-response style similar to black spirituals and other African American musical traditions. The song and the way it is shown present a 
dichotomy between the characters, with Blake as the good-natured hero, supported by allies, and Connors as his outcast antithesis. Blake's character, irrespective of his race, easily falls into the mold of the singing cowboy, embodying honesty and hard work, and defying degrading stereotypes of African Americans. Blake's first ballad thus uses the familiarity of the singing cowboy to appeal to both white and black audiences and to disrupt stereotypical expectations some whites might have for black characters. At the same time, for African American audiences, the call-and-response element of Blake's songs allow black audiences to explore African American cultural history without the intrusion of white definitions of it.

Williams's call-and-response is both literal and figurative in Harlem Rides the Range. During Blake's ballads, the other cowboys join in, responding to his initial call. In his analysis of call-and-response in August Wilson's play, The Piano Lesson, Devon Boan locates call-and-response within the black folk tradition (264). In addition to this, the structure of the two narratives of call-and-response is linear because the direction of the interaction "is not toward resolution or even progress, but toward an appropriate response to the call" (264). Blake's ballads evidence Boan's claims about the pattern of call-and-response, illustrating the literal version of the tradition in the film. Figuratively, however, Blake's ballads extend outside of the film through the appeal of the singing cowboy himself. In other words, the singing cowboy film appeals to both white and black audiences; however, with a black singing cowboy as the lead, this appeal models African American potential despite segregation and exclusionary laws directed towards African Americans in their everyday lives. This dynamic calls out to African American audiences to explore black identity despite racism and segregationist tactics.

By participating in familiar cinematic forms, Harlem Rides the Range is also able to critique them. For example, in some of Gene Autry's films, heroes are racially separated from antiheroes. In The Singing Vagabond (1935), Autry saves a young woman, Lettie Morgan (Ann Rutherford) from being swindled by a blackface minstrel as well as a gang of thieves. While Lettie's exploiter is not African American, his blackface performance sets him apart from other whites. In Rootin' Tootin Rhythm (1937), Autry pursues cattle rustlers named Apache Kid and Black Jim, both racialized figures that the Anglo cowboy must defeat. In both of these films, Autry's songs highlight his goodness and amiability in distinction to the villains. While Williams also uses music to separate his heroes and villains, he does so without racial distinction, therefore demonstrating cultural inclusion for African American audiences. Filmmakers and screenwriters like Williams thus challenged "the prevailing function of race as a signifier in American cinema," particularly the western (Leyda 50).

Blake's second and last song, "Prairie Flower," reinforces and subverts the traditional singing cowboy western as it foreshadows his relationship with Miss Dennison (Artie Young). During the scene, as he rides alone, Blake pulls from his pocket a picture of Miss Dennison, which was taken when Blake discovered blood at her father's ranch. "Prairie Flower" avoids references to black spiritual traditions in order to focus on a woman's love. The lyrics compare femininity to the frontier's wildflowers, echoing the contents of typical cowboy ballads. At the same time, the song subverts the traditional elements of the western. Before Blake begins singing, Cactus (John Thomas) tells Mr. Watson that he has discovered old Tex's body, and that he had been shot from behind. When Blake arrives and sings his song, it draws the attention of other ranch hands that 
accompany him with guitars, as well as Watson, who subsequently enlists Blake to solve the murder mystery. It is the song, therefore, that cues Blake's new role in the film: cowboy detective. Williams blends genres in order to appeal to a wide audience (Gaines 4). More importantly, the combination of elements from western and detective genres enable the community of the film to come together to solve the mystery, making it an inclusive space. While the blending of genres certainly appealed to a wider audience demographic, at the same time, Williams's alteration to the traditional western incorporates an African American perspective in the historiography of the genre, something largely ignored when Harlem Rides the Range was made. Now, however, this alteration functions as an example of African American filmmakers' and screenwriters' contributions to early era cinema.

Blake's role as a singing cowboy provides the means by which Williams can both adhere to and disrupt the western, and also subvert the off-screen marginalization of African American actors. In his analysis of black identity in film, Lars Lierow argues that earlier eras of black filmmakers like Oscar Micheaux "portrayed an ambitious range of African American characters," but he also included "vice and corruption within the black community" (4). This duality emerged for filmmakers like Micheaux and Williams early in the film era, as well as later during the 1960s and 1970s, because black filmmakers had to "contend with censorship boards and black critics who sought to foster a less ambiguous, positive, and moralistic image" (4). Aware of this double standard imposed by racism, Williams adopts a duality with the elements of his film that seemingly adhere to Hollywood standards, such as the figure of the heroic cowboy. Leyda posits "Bob Blake succeeded in providing young African Americans with a brave, strong, and patriotic American hero by adopting many of the Hollywood conventions of the cowboy image" (57). Through the character of Blake, Williams demonstrates that African Americans can work in starring roles and speak to some of the major myths and symbols of American culture. Furthermore, in an era consumed by "undue preoccupation with the ethnic, racial, and class identity of the unemployed" (Bauman and Coode 61), Blake removes the stigma of these marginalized groups by bringing them to the center of American culture in the form of the western.

21 Williams's character development both appeals to and subverts stereotypes of African Americans. According to Leyda, "the commercial success of the black westerns depended on their conforming to the western genre's iconography: costume, props, plots, setting, and characters" (56). Two of these characters, Dusty (Lucius Brooks) and Slim Perkins (F.E. Miller), hark back to Hollywood's one-dimensional depictions of African Americans. Dusty, for example, provides comic relief through his obsession with food and his capacity to be easily frightened (Gaines 59). Along the same lines, slim pretends to be an excellent shot, although he ironically never hits his mark. Scenes throughout the film present Dusty and Slim as superstitious and easily befuddled in ways which would not fool Blake and Cactus, the film's heroes. Hollywood frequently offered African Americans roles like Dusty's and Slim's. On the surface, they provide familiarity and comic relief; however Williams complicates these roles later in the film.

Despite first impressions of Dusty and Slim, which could place them in a minstrel tradition, Williams deploys African American vernacular speech to counter any gesture towards minstrelsy. While Hollywood directors consistently asked black actors to speak in parodic dialect for the amusement of white audiences who would laugh at rather 
than with them, Dusty and Slim, use dialect to subversively communicate with one another in ways that whites may not understand, but that would let blacks in on the joke. During a comedic interlude, for example, the two characters speak in dialect as they attempt to conduct their own side investigations to help Blake. At the end of the brief scene, they mistake covered furniture for a ghost. For African American audiences, Dusty's and Slim's language signifies; it participates in what Henry Louis Gates calls "the closed black vernacular tradition... of reference and representation, of connotation and denotation, of truth and understanding... in the black formal literary traditions and in the tricksters found in black myths" (xxi). Dusty's and Slim's multivocality demonstrates awareness of Anglo expectations, but also appeals to a black coterie. When employed by black directors and actors for black audiences, dialect undermines white expectations and consequently refuses to compromise African American culture and identity. Williams's film, then, is informed by the trickster traditions Gates outlines: the very moments when he seems to most fulfill white expectations of blacks are the ones when he is most profoundly subverting them.

Williams uses traditional tensions in westerns such as the battle between good and evil, in order to both speak to this tradition and circumvent it. A standard trope of the western in a number of John Wayne movies, or even Sergio Leone's Dollars Trilogy, good cowboys battle greedy ranchers, misogynistic men, and cattle rustlers. Blake's character contributes to the long-standing tradition of the good, honest cowboy seen in literature and later, film up to the 1970s. Blake evidences many of the traits of a heroic cowboy. He is honest, hard-working, and an excellent marksman. Throughout the film, he triumphs over overwhelming odds. For instance, Bradley (Clarence Brooks) and Connors, the film's villains, plant one of Blake's lost gloves at the scene of a crime, which causes the Sheriff (Wade Dumas) to arrest Blake on suspicion of murder. While incarcerated, Blake dexterously retrieves the keys to his cell using a rope trick. Once he escapes, he decides to get to the bottom of Dennison's disappearance and old Tex's death. While behind bars, Blake had overheard the Sheriff talking to Bradley on the telephone, and he realizes that Bradley intends to murder Miss Dennison so that she cannot inherit her father's land and the hidden radium mine beneath it. Once Blake rescues Miss Dennison, he single-handedly fends off six ne'er-do-wells. The sounds of his bullets echoing off of the canyon walls finally bring the sheriff, Cactus, and other allies to assist him, and Blake's mission succeeds. Like the heroes of many westerns of the era, he triumphs over long odds.

A typical trope in westerns, such as associating gross materialism with villains, appears in Harlem Rides the Range. Williams's film almost foreshadows Gene Autry's singing cowboy films like Gaucho Serenade and later, Jimmy Stewart in Broken Arrow in that gross materialists, whether they be greedy ranchers or imperialist in nature, represent a large swath of the western's plot. In Williams's film, the greedy materialist is Bradley, a villain who hopes to eliminate the Dennisons in order to reap the profit of the radium mine on their property. The tensions over money in Williams's film resonated with Great Depression audiences. The greedy villains, obsessed with wealth, function as the anti-heroes who are contrasted against the humble, hard-working cowboys. In contrast to the realities outside of film where hard workers did not always find employment and where good people suffered, in westerns like Williams's, workers could triumph over greedy villains and restore hope, at least temporarily, to the hearts of downtrodden audience members. 
Because westerns help reinforce the "nation's imaginary picture of itself," by turning to the genre, Williams expands this vision through the incorporation of African American culture (Leyda 51). Black audiences could then see inclusive representations of themselves, while white audiences confronted the multiracial constitution of the nation.

\section{Conclusion}

Until the 1930s, few minority filmmakers created westerns. When Williams turns to this mainstream genre, he both deployed and disrupted its familiar characteristics, namely in the form of the singing cowboy, the multi-faceted nature of the characters, and the good versus evil trope. In doing so, Williams provides an inclusive space within American culture for African Americans, one in which African Americans can explore black identity. Due to his precarious position off-screen, in particular segregation via Jim Crow laws, Williams used a popular, mainstream genre to introduce black identity on its own terms. At the same time, he helps initiate a historiography of black cinema that focuses on forming black identity and communities in films such as Sydney Portier's Buck and the Preacher (1972), Spike Lee's Do the Right Thing (1989), Mario Van Peebles's Posse (1993), Ava DuVernay's 13th (2016), and George Tillman's The Hate U Give (2018), to name a few.

\section{BIBLIOGRAPHY}

Bauman, John F., and Thomas H Coode. "Women and Minorities in the Depression." The Great Depression, edited by Don Nardo, Greenhaven P, 2000, pp. 62-74.

Boan, Devon. "Call-And-Response: Parallel 'Slave Narrative' in August Wilson's The Piano Lesson." African American Review, vol. 32 no. 2, 1998, pp. 263-271.

Bogle, Donald. Bright Boulevards, Bold Dreams: The Story of Black Hollywood. Ballantine Books, 2005.

---. Toms, Coons, Mulattoes, Mammies, and Bucks: An Interpretative History of Blacks in American Films. Continuum, 1994.

Cohen, Lizabeth. Making a New Deal: Industrial Workers in Chicago, 1919-1939. Cambridge UP, 2008.

Cripps, Thomas. “The Films of Spencer Williams." Black American Literature Forum, vol. 12, no. 4, 1978, pp. 128-134.

Denning, Michael. The Cultural Front: The Laboring of American Culture in the Twentieth Century. Verso, 1997.

Dinerstein, Joel. “'Emergent Noir': Film Noir and the Great Depression in High Sierra (1941) and This Gun for Hire (1942).” Journal of American Studies, vol. 42, no. 3, 2008, pp. 415-448.

Fenster, Mark. "Preparing the Audience, Informing the Performers: John A. Lomax and Cowboy Songs and Other Frontier Ballads." American Music, vol. 7, no. 3, 1989, pp. 260-277. 
Francis, Terri. “Looking Sharp.” Transition, vol. 112, 2013, pp. 32-45.

Gaines, Jane M. “'The Scar of Shame': Skin Color and Caste in Black Silent Melodrama.” Cinema Journal, vol. 26, no. 4, 1987, pp. 3-21.

---. "The White in the Race Movie Audience." Going to the Movies: Hollywood and the Social Experience of Cinema, edited by Richard Maltby, Melvyn Stokes, and Robert C. Allen, U of Exeter P, 2007, pp. 60-75.

Gates Jr., Henry Louis. The Signifying Monkey: A Theory of African-American Literary Criticism. Oxford UP, 1988.

Harlem Rides the Range. Directed by Richard C. Kahn, performances by Herbert Jeffries, Lucius Brooks, F.E. Miller, Hollywood Pictures Corporation, 1939.

Heyde, Paul C. “African Americans in Cinema: The First Half Century.” Black Camera, vol. 18, no. 2, 2003, pp. 8-11.

---. “He Was Reluctant About Asking for Food.” New York Times, 11 Nov. 1937.

Hoyt, Edwin P. "Life and Leisure in the Depression." The Great Depression, edited by Don Nardo, Greenhaven P, 2000, pp. 75-87.

Kagan, Norman. “The Dark Horse Operas: A Film Article.” Negro History Bulletin, vol. 36, no. 1, 1973, pp. 13-14.

Leyda, Julia. "Black-Audience Westerns and the Politics of Cultural Identification in the 1930s." Cinema Journal, vol. 42, no. 1, 2002, pp. 46-70.

Lierow, Lars. “The ‘Black Man's Vision of the World': Rediscovering Black Arts Filmmaking and the Struggle for a Black Cinematic Aesthetic." Black Camera, vol. 4, no. 2, 2013, pp. 3-21.

Mattacheo, Andrea. "Shadows of Forgotten Men. Film Noir and the Great Depression's Imagination: 'Murder, My Sweet.” History of Economic Ideas, vol. 22, no. 3, 2014, pp. 167-177.

McElvaine, Robert S. "Depression-Era Cinema Reflected Social Values.” The Great Depression, edited by Don Nardo, Greenhaven P, 2000, pp. 88-97.

Seward, Adrienne Lanier. “Spencer Williams.” Black Camera, vol. 4, no. 1, 1989, p. 3.

Smyth, J.E. "Classical Hollywood and the Filmic Writing of Interracial History, 1931-1939." Mixed Race Hollywood, edited by Mary Beltrán and Camilla Fojas, New York UP, 2008, pp. 23-44.

Stewart, Jacqueline. "Discovering Black Film History: Tracing the Tyler, Texas Black Film Collection." Film History, vol. 23, no. 2, 2011, pp. 147-173.

Tyree, Tia C. M., and Liezille J. Jacobs. "Can You Save Me? Black Male Superheroes in Hollywood Film.” Spectrum: A Journal of Black Men, vol. 23, no. 1, 2014, pp. 1-24.

Vander Wel, Stephanie. “The Lavender Cowboy and 'The She-Buckaroo': Gene Autry, Patsy Montana, and Depression-Era Gender Roles.” The Musical Quarterly, vol. 95, no. 2/3, 2012, pp. 207-251.

\section{ABSTRACTS}

While the 1930s in the United States is oftentimes overshadowed by the effects of the Great Depression on everything from the economy to everyday life, at the same time, it was an era filled with avid moviegoers. The advent of sound in film provided a unique opportunity for 
minority filmmakers to contribute to the early cinema. African American filmmakers like Spencer Williams, for example, turned to the genre of the western because it was a familiar genre for both mainstream and minority audiences. It was also cheap to produce, a boon for screenwriters and directors like Williams with limited budgets. By adopting a popular genre like the western, Williams brought minority perspectives to the silver screen during a period when these perspectives were often met with hostility or completely ignored within mainstream culture. In doing so, Williams includes elements of the western that are familiar to audiences, such as the singing cowboy genre. He then pairs this familiar element with subversive ones like the use of dialect and the trickster figure. Through an analysis of Williams's adhesion to and disruption of tendencies in the western, it becomes clear how he appealed to both white and black audiences during a period of poverty, unemployment, and segregation. In addition to this, a closer look at William's manipulation of a western like Harlem Rides the Range helps locate and explore black identity in early cinema history.

\section{INDEX}

Keywords: Rides the Range, race in cinema, Spencer Williams, early American film, American West, the Western

\section{AUTHOR}

\section{SUSAN SAVAGE LEE}

Susan Savage Lee is Department Chairof Modern Languages and Co-Chair of African American Studies at Jefferson Community and Technical College. Dr. Lee received her doctorate in American Studies from Saint Louis University. She specializes in comparative literature and film (the US and Argentina), Native American Studies, and African American Studies. 